\title{
MENINGKATKAN DAYA INGAT ANAK MELALUI PERMAINAN TEBAK GAMBAR DI KELOMPOK B PAUD BINTANG 9 KELURAHAN LALOLARA KEC. KAMBU KOTA KENDARI
}

\author{
Wd. Helmita ${ }^{1)}$, Salwiah ${ }^{2)}$ \\ ${ }^{1}$ Alumni Jurusan PG-PAUD, Universitas Halu Oleo. Jln. H.E.A Mokodompit, Kendari 93232, \\ Indonesia. \\ ${ }^{2}$ Dosen Jurusan PG-PAUD, Universitas Halu Oleo. Jln. H.E.A Mokodompit, Kendari 93232, \\ Indonesia \\ E-mail/Telp: helmitaode@gmail.com / 085395666053
}

\begin{abstract}
Abstrak
Penelitian ini bertujuan untuk meningkatkan daya ingat anak melalui permainan tebak gambar di kelompok B PAUD Bintang 9 Kelurahan Lalolara Kec. Kambu. Subjek dalam penelitian ini adalah guru dan anak didik yang berjumlah 16 orang yang terdiri atas 8 orang anak perempuan dan 8 orang anak laki-laki dengan rentang usia 4-5 tahun. Jenis penelitian ini adalah penelitian tindakan kelas yang dilaksanakan dalam dua siklus. Pengumpulan data dalam penelitian ini menggunakan metode observasi, wawancara dan dokumentasi. Berdasarkan analisis data hasil observasi aktivitas mengajar guru pada siklus I diperoleh persentase ketercapaian sebesar 73,3\%, aktivitas belajar anak didik diperoleh persentase ketercapaian sebesar $71,42 \%$ sedangkan hasil belajar anak berupa peningkatan daya ingat anak melalui permainan tebak gambar sebelum dilakukan tindakan sebesar 35,20\% anak memperoleh nilai BSB dan BSH kemudian meningkat pada siklus I sebesar 70\%. Pada siklus II, persentase ketercapaian aktivitas mengajar guru mengalami peningkatan menjadi 93,33\%, persentase ketercapaian aktivitas belajar anak didik juga mengalami peningkatan menjadi $92,85 \%$ dan hasil belajar anak berupa peningkatan daya ingat anak melalui permainan tebak gambar meningkat sebesar $88,20 \%$.
\end{abstract}

Kata Kunci: Daya Ingat Anak, Permainan, Tebak Gambar.

\section{INCREASING CHILDREN'S MEMORY THROUGH GAME GUESS IMAGES IN GROUP B PAUD BINTANG 9 KELURAHAN LALOLARA KEC. KAMBU KOTA KENDARI}

\section{Abstract}

This study aims to improve children's memory through guessing games in group B PAUD Bintang 9 Kelurahan Lalolara Kec. Kambu. This research is expected to enrich or add data about the study of science, especially those relating to memory of early childhood. The subjects in this study were 16 teachers and students consisting of 8 girls and 8 boys with 4-5 years of age. This type of research is classroom action research conducted in two cycles. Data collection in this study using the method of observation, interviews and documentation. Based on the analysis of observational data on teacher teaching activities in the first cycle obtained an achievement percentage of $73.3 \%$, learning activities of students obtained an achievement percentage of $71.42 \%$ while the learning outcomes of children in the form of increasing children's memory through guessing games before an action of 35 , $20 \%$ of children obtain BSB and BSH values then increase in cycle I by 70\%. In the second cycle, the percentage of achievement of teacher teaching activities increased to $93.33 \%$, the percentage of achievement of students' learning activities also increased to $92.85 \%$ and children's learning outcomes in the form of improving children's memory through guessing games increased by $88.20 \%$.

Keywords: Child Memory, Game, Guess Images

\section{PENDAHULUAN}

Pendidikan anak usia dini adalah suatu upaya pembinaan yang di tujukan kepada anak sejak usia dini yang dilakukan melalui pemberian rangsangan pendidikan untuk membantu pertumbuhan dan perkembangan jasmani dan rohani agar anak memiliki kesiapan dalam memasuki pendidikan dasar kehidupan tahap berikutnya. Sesuai Undang-Undang Nomor 20 Tahun 2003 tentang 
Sistem Pendidikan Nasional, pada pasal 28 menyebutkan bahwa Pendidikan Anak Usia Dini (PAUD) diselenggarakan sebelum jenjang pendidikan dasar. Pendidikan anak usia dini dapat diselenggarakan melalui jalur formal, nonformal, serta informal, dan terbagi atas: Tempat Penitipan Anak (TPA), Kelompok Bermain (KB), Taman Kanak-kanak (TK), Raudatul Athfal (RA), atau bentuk lain yang sederajat. Pendidikan anak usia dini di lakukan melalui pemberian rangsangan untuk membantu pertumbuhan serta perkembangan jasmani dan rohani anak agar memiliki kesiapan dalam memasuki pendidikan lebih lanjut (Depdiknas, $2004: 1$ ).

Anak usia dini adalah generasi penerus bangsa yang memiliki karakteristik berbeda dengan anak usia lebih atas sehingga pendidikan anak perlu untuk dikhususkan. Pendidikan Anak Usia Dini (PAUD) telah berkembang dengan pesat dan mendapat perhatian yang luar biasa terutama di negara-negara maju. Oleh karena itu, menurut ilmu tersebut pengembangan kapasitas manusia akan lebih mudah apabila dilakukan sejak usia dini (Slamet Suyanto, 2005: 1).

Anak usia dini memerlukan berbagai kegiatan untuk mengorganisasi informasi di dalam otak, apabila anak hanya diberi sedikit petunjuk, maka anak akan mengalami kesulitan untuk memahami apa yang telah anak lihat dan pelajari. Anak usia dini memerlukan kegiatan pembelajaran yang menarik di kelas. Sekolah berperan penting untuk menumbuhkan semua aspek perkembangan pada anak. Salah satu perkembangan yang dapat dioptimalkan yaitu aspek kognitif.

Salah satu bidang pengembangan yang diajarkan di PAUD adalah bidang pengembangan kognitif. Untuk menyusun model pembelajaran kognitif, guru diharapkan mengacu kepada pedoman pembelajaran ini. Kemampuan kognitif dipersiapkan guru untuk meningkatkan kemampuan dan kreativitas anak sesuai dengan tahap perkembangannya. Kemampuan kognitif anak sangat berhubungan dengan kemampuan daya ingat yang dimilikinya. Daya ingat bagi anak sangat penting, karena daya ingat menjadi fungsi yang sangat penting untuk ingatan anak. Saat anak menerima pembelajaran di sekolah, anak sangat membutuhkan memori untuk menyimpan sesuatu, misalnya pelajaran apa yang telah di ajarkan oleh guru kepada anak agar mudah di ingat dan untuk keesokan harinya dan seterusnya. Tanpa menggunakan daya ingat anak sulit mengingat apa yang di ajarkan guru terhadapnya.

Berdasarkan hasil observasi awal yang di lakukan peneliti di PAUD Bintang Sembilan, menunjukkan bahwa dari 16 orang anak terdapat 10 anak atau $52 \%$ yang tidak mampu meningkat daya ingat melalui permainan tebak gambar. Hal ini disebabkan metode guru yang sangat monoton dan pembelajaran yang kurang menarik sehingga anak bosan.

Permasalahan pada PAUD Bintang Sembilan diatas dapat diatasi dengan menggunakan media gambar dalam permainan tebak gambar untuk membantu kesulitan daya ingat anak. Permainan tebak gambar merupakan cara atau gaya dalam proses pembelajaran anak usia dini yang lebih sesuai untuk meningkatkan minat belajar anak, sehingga proses pembelajaran dapat bertujuan untuk meningkatkan daya ingat. Permainan tebak gambar juga merupakan salah satu pengembangan dari permainan edukatif sebagai permainan yang membuat anak senang untuk belajar.

Permainan tebak gambar anak dapat memahami dan mengingat sesuatu yang dilihatnya. Permainan tebak gambar memiliki peranan penting dalam meningkatkan hasil belajar siswa. Hal ini mengacu pada pernyataan Winataputra, (2005:55) yang menyatakan bahwa penglihatan (visual) memiliki komposisi paling besar (75\%) dalam hal rata-rata jumlah informasi yang dapat diperoleh seseorang. Informasi yang diperoleh melalui penglihatan juga lebih mudah ditangkap dan diingat oleh ingatan seseorang. Apabila permainan tebak gambar didukung oleh metode pembelajaran yang sesuai, maka dapat membawa siswa di lingkungan belajar yang aktif dan menyenangkan.

Pembelajaran sangat memungkinkan untuk menggunakan permainan tebak gambar. Apalagi di dunia modern ini, dimana media gambar dapat dengan mudah dibuat atau ditemukan dengan bantuan komputer dan internet. Penerapannya pun sangat mudah, karena tidak memerlukan fasilitas dan sarana khusus, serta dapat diterapkan kepada hampir setiap kelompok peserta didik tanpa melihat usia atau latar belakang lainnya. Kemudian yang terpenting adalah bagaimana guru memadukannya dengan materi dan metode yang sesuai. Sehingga dari sana kita dapat melihat hal 
apa yang diperlukan guru agar mutu dirinya bisa berkembang.

\section{METODE}

Penelitian Tindakan Kelas (PTK) atau Classroom Action Research (CAR). merupakan bagian dari penelitian tindakan (action research) yang dilakukan oleh guru dan dosen di kelas (sekolah dan perguruan tinggi) tempat ia mengajar yang bertujuan memperbaiki dan meningkatkan kualitas dan kuantitas proses pembelajaran di kelas Heris \& Afrilianto (2017:45).

Subjek dalam penelitian ini adalah guru dan anak didik yang berjumlah 16 orang yang terdiri atas 8 orang anak perempuan dan 8 orang anak laki-laki dengan rentang usia 5-6 tahun.

Adapun faktor-faktor yang diteliti dan diamati dalam penelitian ini adalah: a) faktor anak didik, untuk melihat aktivitas anak dalam menggunakan media kartu berpasangan dan melihat peningkatan kemampuan kognitif anak melalui media kartu berpasangan dan b) faktor guru, untuk melihat bagaimana guru dapat menggunakan media kartu berpasangan dalam meningkatkan daya ingat anak melalui permainan tebak gambar di kelompok B PAUD Bintang 9 Kelurahan Lalolara Kec. Kambu Kota Kendari.

Data yang diperoleh dari penelitian ini adalah data kualitatif dan data kuantitatif. Data kualitatif digunakan untuk menghimpun data tentang pelaksanaan proses pembelajaran yang dilaksanakan oleh guru dan anak. Data kualitatif diperoleh melalui lembar observasi. Sedangkan data kuantitatif menghimpun data tentang peningkatan kognitif anak melalui media kartu angka yang diperoleh melalui lembar instrumen/evaluasi yang dilakukan pada setiap pertemuan dan diakhir siklus tindakan.

Indikator kinerja dalam penelitian ini ditetapkan oleh PAUD Bintang 9 Kelurahan Lalolara Kec. Kambu Kota Kendari, yang terdiri dari indikator proses pembelajaran dan indikator hasil (nilai) anak didik. Dari segi indikator proses pembelajaran, tindakan dikatakan berhasil apabila minimal $90 \%$ proses pelaksanaan tindakan sesuai dengan skenario pembelajaran, baik yang dilakukan oleh guru maupun anak didik. Dari segi indikator hasil, tindakan dikatakan berhasil apabila anak didik telah mencapai nilai berkembang sesuai harapan (BSH) dan berkembang sangat baik (BSB) minimal $75 \%$ baik secara individual maupun klasikal.

\section{HASIL DAN PEMBAHASAN}

Sebelum kegiatan penelitian ini dilaksanakan, peneliti terlebih dahulu melakukan pertemuan awal dengan Kepala sekolah PAUD Bintang 9 yang beralamat di Kel. Lalolara Kec. Kambu Kota Kendari yaitu pada tanggal 20 Juli. Pertemuan tersebut bermaksud untuk menyampaikan tujuan dari peneliti, yaitu mengadakan penelitian di PAUD Bintang 9 Kelurahan Lalolara Kec. Kambu.

Sehari sebelum melakukan observasi awal, langkah pertama yang dilakukan peneliti yaitu terlebih dahulu menyiapkan media yang akan digunakan dalam kegiatan peningkatan kemampuan daya ingat. Berdasarkan hasil observasi dan dilanjutkan dengan wawancara singkat dengan guru Kelompok B PAUD Bintang 9 Kelurahan Lalolara Kec. Kambu yaitu untuk meningkatkan kemampuan daya ingat anak.

Berdasarkan observasi dan wawancara yang dilaukan peneliti menunjukan bahwa peningkatan daya ingat melalui permainan tebak gambar di PAUD Bintang 9 Kelurahan Lalolara Kec. Kambu masih sangat rendah yaitu berada dalam kategori mulai berkembang (MB) dan belum berkembang (BB).

Penelitian dilakukan dengan tindakan siklus I yang terdiri dari 4 kali pertemuan dan mengikuti empat tahapan kegiatan yaitu perencanaan, pelakanaan tindakan, observasi dan evaluasi, dan refleksi. Hal-hal yang dilakukan dalam tahap ini adalah menyiapkan RKH dan RKM, media yang dibutuhkan, lembar observasi anak dan guru serta alat evaluasi/penilaian.

Pelaksanaan tindakan Siklus I pertemuan I dilaksanakan pada hari Senin, 23 Juli 2018 pada pukul 07.30 - 10.00 WITA di kelompok B PAUD Bintang 9 kelurahan Lalolara, dengan menggunakan tema diri sendiri dan sub tema kepala . Adapun indikator yang harus dicapai anak didik pada setiap pertemuan yaitu: anak dapat menyebutkan bagian anggota tubuh, anak dapat menebak dengan benar gambar bagian anggota tubuh, menebak dengan benar fungsi gambar anggota tubuh yang di lihat, anak dapat memasangkan lambang bilangan sesuai jumlah gambar anggota tubuh. Sebelum kegitan pembelajaran dimulai, guru telah menyiapkan beberapa media pembelajaran, aktifitas yang dilakukan setiap hari yaitu sebelum memulai pembelajaran dikelas anak didik dirapikan, 
kemudian mengucapkan salam dan berdo'a sebelum belajar

Kegitan inti guru melakukan apersepsi dengan menunjukkan gambar anggota tubuh dan anak bersama-sama menebak gambar yang ditunjuk guru tersebut. Kegiatan dilanjutkan, anak yang sudah menebak antusias menebak gambar yang ditunjukkan, namun pada gambar punggung, pinggang paha dan betis, hanya beberapa anak yang masih semangat berteriak, banyak anak yang diam ketika gambar yang dilihat membingungkan mereka. Guru kemudian membantu dengan menunjukkan gambar yang hampir sama tersebut dan menjelaskan perbedaannya. Ketika diminta mengulangi masih banyak anak yang lupa, gambar yang paling mereka ingat adalah gambar kepala, tangan dan kaki. Sementara itu peneliti bertugas mempersiapkan media. Selanjutnya guru dan peneliti memberi penjelasan bahwa hari ini akan melaksanakan permainan tebak gambar, dan menjelaskan aturan permainannya. Aturan permainan pada lomba menebak yaitu anak yang harus dengan cepat menebak gambar yang dilihat, dan menyebutkan fungsi gambar yang dilihat, Ketika menebak anak menyebutkan fungsi dari gambar yang ditebaknya. Kemudian guru bertanya pada anak "bagaimana anak-anak, sudah dimengerti?", anak menjawab "sudah bu guru". Guru kemudian memilih anak yang menebak duluan "Ayo siapa yang menebak duluan gambar yang ibu guru perlihatkan, nanti dia dapat bintang empat!", anak-anak bersahutsahutan mengatakan "aku, aku, aku...", suasana menjadi gaduh kemudian. Selanjutnya guru memperlihatkan salah satu gambar anggota tubuh untuk di tebak. Anak yang menebak duluan kemudian menyebutkan fungsi anggota anggota tubuh yang di tebaknya. Anak yang dapat menebak dan mengingat fungsi anggota tubuh berhak mendapat bintang empat.

Kegiatan akhir anak-anak dipersilakan istirahat dan membereskan alat main yang digunakan. Setelah itu guru memberikan kesimpulan tentang kegiatan yang dilakukan hari ini yaitu peningkatan kemampuan daya ingat melalui permainan tebak gambar, setelah itu menyanyikan beberapa lagu dan mengucapkan doa sebelum pulang.

Pelaksanaan tindakan Siklus I pertemuan II dilaksanakan pada hari Senin, 24 Juli 2018 pada pukul 07.30 - 10.00 WITA di kelompok B PAUD Bintang 9 kelurahan Lalolara, dengan menggunakan tema diri sendiri dan sub tema anggot tubuh. Adapun indikator yang harus dicapai anak didik pada setiap pertemuan yaitu: anak dapat menyebutkan bagian anggota tubuh, anak dapat menebak dengan benar gambar bagian anggota tubuh, menebak dengan benar fungsi gambar anggota tubuh yang di lihat, anak dapat memasangkan lambang bilangan sesuai jumlah gambar anggota tubuh. Sebelum kegitan pembelajaran dimulai, guru telah menyiapkan beberapa media pembelajaran, aktifitas yang dilakukan setiap hari yaitu sebelum memulai pembelajaran dikelas anak didik dirapikan, kemudian mengucapkan salam dan berdoa sebelum belajar.

Kegitan inti guru melakukan apersepsi dengan menunjukkan gambar anggota tubuh dan anak bersama-sama menebak gambar yang ditunjuk guru tersebut. Kegiatan dilanjutkan, anak yang sudah menebak antusias menebak gambar yang ditunjukkan, namun pada gambar punggung, pinggang paha dan betis, hanya beberapa anak yang masih semangat berteriak, banyak anak yang diam ketika gambar yang dilihat membingungkan mereka. Guru kemudian membantu dengan menunjukkan gambar yang hampir sama tersebut dan menjelaskan perbedaannya. Saat pertemuan kedua ini anakanak masih terkondisi yaitu terlihat dari antusiasme namun ada beberapa anak yang masih kurang dalam mengikuti permainan.

Ketika diminta mengulangi masih banyak anak yang lupa, gambar yang paling mereka ingat adalah gambar kepala, tangan dan kaki. Sementara itu peneliti bertugas mempersiapkan media. Selanjutnya guru dan peneliti memberi penjelasan bahwa hari ini akan melaksanakan permainan tebak gambar, dan menjelaskan aturan permainannya. Aturan permainan pada lomba menebak yaitu anak yang harus dengan cepat menebak gambar yang dilihat, dan menyebutkan fungsi gambar yang dilihat, Ketika menebak anak menyebutkan fungsi dari gambar yang ditebaknya. Selanjutnya guru memperlihatkan salah satu gambar anggota tubuh untuk di tebak. Anak yang menebak duluan kemudian menyebutkan fungsi anggota anggota tubuh yang di tebaknya. Anak yang dapat menebak dan mengingat fungsi anggota tubuh berhak mendapat bintang empat.

Kegiatan akhir anak-anak dipersilakan istirahat dan membereskan alat main yang digunakan. Setelah itu guru memberikan kesimpulan tentang kegiatan yang dilakukan hari ini yaitu peningkatan kemampuan daya ingat melalui permainan tebak gambar, setelah 
itu menyanyikan beberapa lagu dan mengucapkan doa sebelum pulang.

Pelaksanaan tindakan Siklus I pertemuan III dilaksanakan pada hari Rabu, 25 Juli 2018 pada pukul 07.30 - 10.00 WITA di kelompok B PAUD Bintang 9 kelurahan Lalolra dengan menggunakan tema Diri sendiri dan sub tema anggota tubuh. Adapun indikator yang harus dicapai anak didik pada setiap pertemuan yaitu: anak dapat menyebutkan bagian anggota tubuh, anak dapat menebak dengan benar gambar bagian anggota tubuh, menebak dengan benar fungsi gambar anggota tubuh yang di lihat, anak dapat memasangkan lambang bilangan sesuai jumlah gambar anggota tubuh. Sebelum kegitan pembelajaran dimulai, guru telah menyiapkan beberapa media pembelajaran, aktifitas yang dilakukan setiap hari yaitu sebelum memulai pembelajaran dikelas anak didik dirapikan, kemudian mengucapkan salam dan berdoa sebelum belajar.

Pada kegiatan inti langkah masih sama seperti pertemuan sebelumnya namun dengan materi yang berbeda. Pada Kegitan inti guru melakukan apersepsi dengan menunjukkan gambar anggota tubuh dan anak bersama-sama menebak gambar yang ditunjuk guru tersebut. Kegiatan dilanjutkan, anak yang sudah menebak antusias menebak gambar yang ditunjukkan, namun pada gambar punggung, pinggang paha dan betis, hanya beberapa anak yang masih semangat berteriak, banyak anak yang diam ketika gambar yang dilihat membingungkan mereka. Guru kemudian membantu dengan menunjukkan gambar yang hampir sama tersebut dan menjelaskan perbedaannya. Guru memberikan semangat bahwa semua pintar dan mampu menebak fungsi gambar yang ditebak kemudian menjelaskan cirri dan fungsi gambar yang ditebak. Selanjutnya guru dan peneliti memberi penjelasan bahwa hari ini akan melaksanakan permainan tebak gambar, dan menjelaskan aturan permainannya. Aturan permainan pada lomba menebak yaitu anak yang harus dengan cepat menebak gambar yang dilihat, dan menyebutkan fungsi gambar yang dilihat, Ketika menebak anak menyebutkan fungsi dari gambar yang ditebaknya. Selanjutnya guru memperlihatkan salah satu gambar anggota tubuh untuk di tebak. Anak yang menebak duluan kemudian menyebutkan fungsi anggota anggota tubuh yang di tebaknya. Anak yang dapat menebak dan mengingat fungsi anggota tubuh berhak mendapat bintang empat. Saat pertemuan ketiga ini anak-anak masih terkondisi yaitu terlihat kurang dari antusiasme anak dalam mengikuti permainan.

Kegiatan akhir anak-anak dipersilakan istirahat dan membereskan alat main yang digunakan. Setelah itu guru memberikan kesimpulan tentang kegiatan yang dilakukan hari ini yaitu peningkatan kemampuan daya ingat melalui permainan tebak gambar, setelah itu menyanyikan beberapa lagu dan mengucapkan doa sebelum pulang.

Pelaksanaan tindakan Siklus I pertemuan IV dilaksanakan pada hari Kamis, 26 Juli 2018 pada pukul $07.30-10.00$ WITA di kelompok B PAUD Bintang 9 kelurahan Lalolara dengan menggunakan tema Diri sendiri dan sub tema anggota tubuh (Badan). Adapun indikator yang harus dicapai anak didik pada setiap pertemuan yaitu: anak dapat menyebutkan bagian anggota tubuh, anak dapat menebak dengan benar gambar bagian anggota tubuh, menebak dengan benar fungsi gambar anggota tubuh yang di lihat, anak dapat memasangkan lambang bilangan sesuai jumlah gambar anggota tubuh. Sebelum kegitan pembelajaran dimulai, guru telah menyiapkan beberapa media pembelajaran, aktifitas yang dilakukan setiap hari yaitu sebelum memulai pembelajaran dikelas anak didik dirapikan, kemudian mengucapkan salam dan berdoa sebelum belajar.

Pada kegiatan inti langkah masih sama seperti pertemuan sebelumnya namun dengan materi yang berbeda. Pada Kegitan inti guru melakukan apersepsi dengan menunjukkan gambar anggota tubuh dan anak bersama-sama menebak gambar yang ditunjuk guru tersebut. Kegiatan dilanjutkan, anak yang sudah menebak antusias menebak gambar yang ditunjukkan, namun pada gambar punggung, pinggang paha dan betis, hanya beberapa anak yang masih semangat berteriak, banyak anak yang diam ketika gambar yang dilihat membingungkan mereka. Guru kemudian membantu dengan menunjukkan gambar yang hampir sama tersebut dan menjelaskan perbedaannya. Guru memberikan semangat bahwa semua pintar dan mampu menebak fungsi gambar yang ditebak kemudian menjelaskan cirri dan fungsi gambar yang ditebak. Selanjutnya guru dan peneliti memberi penjelasan bahwa hari ini akan melaksanakan permainan tebak gambar, dan menjelaskan aturan permainannya. Aturan permainan pada lomba menebak yaitu anak yang harus dengan cepat menebak gambar yang dilihat, dan menyebutkan fungsi gambar yang dilihat, Ketika menebak anak menyebutkan 
fungsi dari gambar yang ditebaknya. Selanjutnya guru memperlihatkan salah satu gambar anggota tubuh untuk di tebak. Anak yang menebak duluan kemudian menyebutkan fungsi anggota anggota tubuh yang di tebaknya. Anak yang dapat menebak dan mengingat fungsi anggota tubuh berhak mendapat bintang empat. Saat pertemuan ketiga ini anak-anak masih terkondisi yaitu terlihat kurang dari antusiasme anak dalam mengikuti permainan.

Kegiatan akhir anak-anak dipersilakan istirahat dan membereskan alat main yang digunakan. Setelah itu guru memberikan kesimpulan tentang kegiatan yang dilakukan hari ini yaitu peningkatan kemampuan daya ingat melalui permainan tebak gambar, setelah itu menyanyikan beberapa lagu dan mengucapkan doa sebelum pulang.

Selama proses pembelajaran berlangsung, guru sebagai observer mengamati jalannya pembelajaran dengan menggunakan lembar observasi untuk guru dan lembar observasi untuk anak. Kegiatan observasi dilakukan bersamaan dengan pelaksanaan tindakan untuk setiap pertemuan pada siklus I.

Hasil analisis observasi mengajar guru sesuai dengan pedoman lembar obsevasi sebanyak 15 aspek yang diamati akan dicapai oleh guru. Pada siklus I skor yang dicapai oleh guru dari 15 aspek hanya 10 aspek setara dengan $73,33 \%$. Aspek yang diamati diantaranya yaitu: (1) guru mengucapkan salam, (2) guru membimbing anak untuk berdoa sebelum belajar, (3) guru mempersiapkan anak belajar, (4) guru menyiapkan media yang yang berhubungan dengan permainan tebak gambr, (5) guru memperkenlkan media pebelajaran berupa kartu gambar, (6) guru mejelaskan permainan yang akan di lakukan, (7) guru meminta anak untuk memperhatikan kegiatan yang akan di lakukan, (8) guru meminta anak menyebutkan bagin anggota tubuh, (9) guru meminta anak menebak dengan benar bagian anggota tubuh, (10) guru memberikan kesimpulan terhadap kegitan yang dilakukan (11) guru membimbing anak untuk berdoa sebelum pulang. Sedangkan yang tidak tercapai sebanyak 4 aspek $26,66 \%$ diantaranya (1) guru tidak mempersiapkan anak untuk belajar (2) guru tidak menyampaikan tujuan pembelajaran (3) guru tidak memantau aktifitas anak, (4) guru tidak mengadakan tanya jawab mengenai kegiatan yang telah berlangsung dari awal hingga akhir kegiatan berlangsung. Untuk lebih jelasnya dapat dilihat pada histogram berikut.

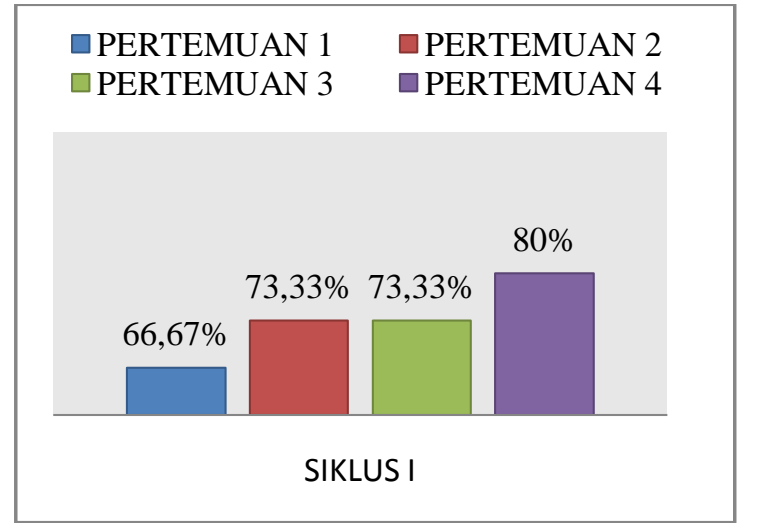

\section{Gambar 1. Histogram Analisis Aktivitas Mengajar Guru Siklus I}

Berdasarkan histogram tersebut aktivitas mengajar guru pada siklus I dengan IV kali pertemuan menunjukkan bahwa dari 15 aspek yang diamati dalam proses pembelajaran aspek yang terlaksana hanya 10 aspek dengan persentase $73,33 \%$ sedangkan yang tidak terlaksana 5 aspek dengan persentase $26,66 \%$ dengan demikian hasil aktivitas mengajar guru pada siklus I belum maksimal sedangkan standar ketercapaian aktivitas mengajar guru yang dicapai $\geq 75 \%$ sehingga dapat dikatakan berhasil.

Dalam proses pembelajaran siklus I aktivitas belajar anak yang diamati menggunakan lembar observasi aktivitas belajar anak terdiri atas 14 aspek. Analisis hasil aktivitas belajar anak pada 14 aspek yang diamati dan harus dicapai oleh anak. Pada siklus I persentase aspek yang diamati mencapai $71,42 \%$ dengan rincian 14 aspek hanya 10 aspek yang dilaksanakan. Aspek yang diamati diantaranya yaitu: (1) guru menyampaikan tujuan pembelajaran, (2) Anak mengucapkan salam, (3) anak mendengarkan guru menyampaikan tujuan pembelajaran, (4) anak mendengarkan guru meyampaikan tujuan pembelajaran, (5), anak mendengarkan guru menyampaikan materi pembelajaran tentang permainan tebak gambar (6), anak dapat menyebutkan bagian anggota tubuh (7), anak mampu menebak dengan benar bagian anggot tubuh (8) anak mampu menebak fungsi anggota tubuh yang telah di tebaknya, (9) anak dapat memasangkan lambang bilangan sesuai jumlah gambar anggota tubuh, (10) anak berani mengemukakan pendapat sendiri (11) anak bernyanyi dan berdoa sebelum pulang. Sedangkan yang belum tercapai sebanyak 4 aspek 28,57\% diantaranya: (1) guru mempersiapkan anak untuk belajar,(2) tidak 
mendengarkan guru menyampaikan tujuan pembelajaran (3) anak tidak mendengarkarkan bimbingan dari guru tentang kegiatan yang dilakukan, (4) anak tidak meakukan tanya jawab dengan guru tenatng kegiatan yang dilakukan.

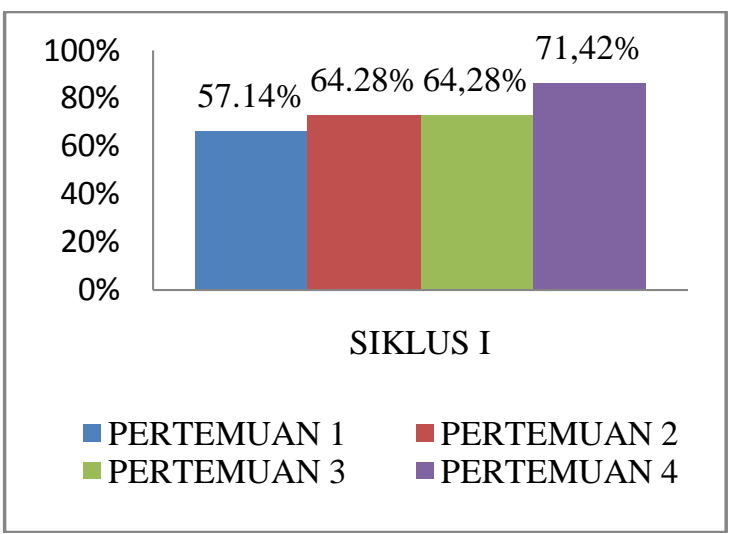

Gambar 2. Histogram Aktivitas Hasil Belajar Anak Siklus I

Berdasarkan histogram tersebut aktivitas hasil belajar anak pada siklus I menunjukkan bahwa dari 14 aspek yang diamati dalam proses pembelajaran aspek yang terlaksana 10 aspek dengan persentase $71,42 \%$, sedangkan yang tidak terlaksana 4 aspek dengan persentase $28,57 \%$, dengan demikian hasil aktivitas belajar anak pada siklus I belum maksimal sedangkan standar ketercapaian aktivitas belajar anak yang harus dicapai $\geq 75 \%$ maka dapat dikatakan berhasil.

Peneliti yang bekerjasama dengan guru kelompok B PAUD Bintang 9 kelurahan Lalolara melakukan evaluasi atau penilaian pada akhir siklus. Hal ini dilakukan untuk mengetahui perkembangan peningkatan kemampuan daya ingat melalui permainan tebak gambar berdasarkan tema/subtema. Dalam pencapaian keberhasilan, anak dikelompokkan dalam empat kategori yaitu: Berkembang Sangat Baik (BSB), Berkembang Sesuai Harapan (BSH), Mulai Berkembang (MB), dan Belum Berkembang (BB).

\begin{tabular}{lcc}
\multicolumn{3}{c}{ Tabel 1. Nilai Klasikal pada Siklus I } \\
\hline \multicolumn{1}{c}{ Kategori } & Jumlah & Persentase \\
$\begin{array}{l}\text { Berkembang Sangat } \\
\text { Baik (BSB) }\end{array}$ & 2 & 12 \\
$\begin{array}{l}\text { Berkembang Sesuai } \\
\text { Harapan (BSH) }\end{array}$ & 4 & 28 \\
$\begin{array}{l}\text { Mulai Berkembang } \\
\text { (MB) }\end{array}$ & 6 & 40 \\
$\begin{array}{l}\text { Belum Berkembang } \\
\text { (BB) Jumlah }\end{array}$ & 3 & 20 \\
& 16 & 100 \\
\hline
\end{tabular}

Berdasarkan hasil yang diperoleh pada Tabel 1. terlihat bahwa secara klasikal kegiatan meningkatkan daya ingat anak melalui media tebak gambar sebagian besar anak sudah dapat melaksanakan kegiatan dengan baik yaitu $40 \%$ anak memperoleh nilai BSB dan BSH namun belum mencapai indikator kinerja yang ditetapkan yaitu $75 \%$ anak memperoleh nilai $\mathrm{BSB}$ dan BSH. Oleh karena itu, guru dan peneliti mendiskusikan kekurangan-kekurangan apa saja yang terdapat pada pelaksanaan tindakan siklus I untuk kemudian diperbaiki dan dilaksanakan pada siklus II.

Dari hasil observasi, maka beberapa hal yang harus diperbaiki adalah guru masih kurang mampu mengelola kelas, masih kurang dalam menyampaikan tujuan pembelajaran yang dilakukan hari ini, guru tidak mengorganisir waktu belajar sesuai dengan apa yang telah direncanakan pada skenario pembelajaran dan guru masih canggung dalam pelaksanaan kegiatan pembelajaran, sehingga anak didik belum mampu menerapkan kegiatan pembelajaran dengan menggunakan media permainan tebak gambar untuk meningkatkan daya ingat anak.

Kegiatan yang dilakukanoleh peneliti pada siklus II sama dengan tindakan yang dilakukan pada siklus I meliputi perencanaan, pelaksanaan tindakan, pengamatan/observasi, dan refleksi. Mengacu pada data hasil temuan observasi, evaluasi dan refleksi pada tahap kegiatan siklus I, maka peneliti bersama guru kelompok B sepakat untuk melaksanakan kegiatan untuk tindakan siklus II dengan lebih optimal dan persiapan yang lebih baik lagi, agar kekurangan-kekurangan yang terdapat pada tindakan siklus I dapat diminimalisir. Dalam perencanaan tindakan ini peneliti kembali menyiapkan hal-hal yang akan dilakukan dalam pembelajaran.

Pelaksanaan tindakan Siklus II pertemuan I dilaksanakan pada hari Senin, 30 Juli 2018 pada pukul 07.30 - 10.00 WITA di kelompok B PAUD Bintang 9 kelurahan Lalolara, dengan menggunakan tema diri sendiri dan sub tema pundak. Adapun indikator yang harus dicapai anak didik pada setiap pertemuan yaitu: anak dapat menyebutkan bagian anggota tubuh, anak dapat menebak dengan benar gambar bagian anggota tubuh, menebak dengan benar fungsi gambar anggota tubuh yang di lihat, anak dapat memasangkan lambang bilangan sesuai jumlah gambar anggota tubuh. Sebelum kegitan pembelajaran dimulai, guru telah menyiapkan 
beberapa media pembelajaran, aktivitas yang dilakukan setiap hari yaitu sebelum memulai pembelajaran dikelas anak didik dirapikan, kemudian mengucapkan salam dan berdoa sebelum belajar.

Kegitan inti guru melakukan apersepsi dengan menunjukkan gambar anggota tubuh dan anak bersama-sama menebak gambar yang ditunjuk guru tersebut. Kegiatan dilanjutkan, anak yang sudah menebak antusias menebak gambar yang ditunjukkan, namun pada gambar punggung, pinggang paha dan betis, hanya beberapa anak yang masih semangat berteriak, banyak anak yang diam ketika gambar yang dilihat membingungkan mereka. Guru kemudian membantu dengan menunjukkan gambar yang hampir sama tersebut dan menjelaskan perbedaannya. Ketika diminta mengulangi masih banyak anak yang lupa, gambar yang paling mereka ingat adalah gambar kepala, tangan dan kaki. Sementara itu peneliti bertugas mempersiapkan media. Selanjutnya guru dan peneliti memberi penjelasan bahwa hari ini akan melaksanakan permainan tebak gambar, dan menjelaskan aturan permainannya. Aturan permainan pada lomba menebak yaitu anak yang harus dengan cepat menebak gambar yang dilihat, dan menyebutkan fungsi gambar yang dilihat, Ketika menebak anak menyebutkan fungsi dari gambar yang ditebaknya. Kemudian guru bertanya pada anak "bagaimana anak-anak, sudah dimengerti?", anak menjawab "sudah bu guru". Guru kemudian memilih anak yang menebak duluan "Ayo siapa yang menebak duluan gambar yang ibu guru perlihatkan, nanti dia dapat bintang empat!", anak-anak bersahutsahutan mengatakan "aku, aku, aku...", suasana menjadi gaduh kemudian. Selanjutnya guru memperlihatkan salah satu gambar anggota tubuh untuk di tebak. Anak yang menebak duluan kemudian menyebutkan fungsi anggota anggota tubuh yang di tebaknya. Anak yang dapat menebak dan mengingat fungsi anggota tubuh berhak mendapat bintang empat.

Kegiatan akhir anak-anak dipersilakan istirahat dan membereskan alat main yang digunakan. Setelah itu guru memberikan kesimpulan tentang kegiatan yang dilakukan hari ini yaitu peningkatan kemampuan daya ingat melalui permainan tebak gambar, setelah itu menyanyikan beberapa lagu dan mengucapkan doa sebelum pulang.

Pelaksanaan tindakan Siklus II pertemuan II dilaksanakan pada hari Senin, 31 Juli 2018 pada pukul 07.30 - 10.00 WITA di kelompok B
PAUD Bintang 9 kelurahan Lalolara, dengan menggunakan tema diri sendiri dan sub tema anggot tubuh. Adapun indikator yang harus dicapai anak didik pada setiap pertemuan yaitu: anak dapat menyebutkan bagian anggota tubuh, anak dapat menebak dengan benar gambar bagian anggota tubuh, menebak dengan benar fungsi gambar anggota tubuh yang di lihat, anak dapat memasangkan lambang bilangan sesuai jumlah gambar anggota tubuh. Sebelum kegitan pembelajaran dimulai, guru telah menyiapkan beberapa media pembelajaran, aktifitas yang dilakukan setiap hari yaitu sebelum memulai pembelajaran dikelas anak didik dirapikan, kemudian mengucapkan salam dan berdoa sebelum belajar.

Kegitan inti guru melakukan apersepsi dengan menunjukkan gambar anggota tubuh dan anak bersama-sama menebak gambar yang ditunjuk guru tersebut. Kegiatan dilanjutkan, anak yang sudah menebak antusias menebak gambar yang ditunjukkan, namun pada gambar punggung, pinggang paha dan betis, hanya beberapa anak yang masih semangat berteriak, banyak anak yang diam ketika gambar yang dilihat membingungkan mereka. Guru kemudian membantu dengan menunjukkan gambar yang hampir sama tersebut dan menjelaskan perbedaannya. Saat pertemuan kedua ini anakanak masih terkondisi yaitu terlihat dari antusiasme namun ada beberapa anak yang masih kurang dalam mengikuti permainan.

Ketika diminta mengulangi masih banyak anak yang lupa, gambar yang paling mereka ingat adalah gambar kepala, tangan dan kaki. Sementara itu peneliti bertugas mempersiapkan media. Selanjutnya guru dan peneliti memberi penjelasan bahwa hari ini akan melaksanakan permainan tebak gambar, dan menjelaskan aturan permainannya. Aturan permainan pada lomba menebak yaitu anak yang harus dengan cepat menebak gambar yang dilihat, dan menyebutkan fungsi gambar yang dilihat, Ketika menebak anak menyebutkan fungsi dari gambar yang ditebaknya. Selanjutnya guru memperlihatkan salah satu gambar anggota tubuh untuk di tebak. Anak yang menebak duluan kemudian menyebutkan fungsi anggota anggota tubuh yang di tebaknya. Anak yang dapat menebak dan mengingat fungsi anggota tubuh berhak mendapat bintang empat.

Kegiatan akhir anak-anak dipersilakan istirahat dan membereskan alat main yang digunakan. Setelah itu guru memberikan kesimpulan tentang kegiatan yang dilakukan 
hari ini yaitu peningkatan kemampuan daya ingat melalui permainan tebak gambar, setelah itu menyanyikan beberapa lagu dan mengucapkan doa sebelum pulang.

Pelaksanaan tindakan Siklus II pertemuan III dilaksanakan pada hari Rabu, 1 Agusus 2018 pada pukul 07.30 - 10.00 WITA di kelompok B PAUD Bintang 9 kelurahan Lalolra dengan menggunakan tema Diri sendiri dan sub tema anggota tubuh. Adapun indikator yang harus dicapai anak didik pada setiap pertemuan yaitu: anak dapat menyebutkan bagian anggota tubuh, anak dapat menebak dengan benar gambar bagian anggota tubuh, menebak dengan benar fungsi gambar anggota tubuh yang di lihat, anak dapat memasangkan lambang bilangan sesuai jumlah gambar anggota tubuh. Sebelum kegitan pembelajaran dimulai, guru telah menyiapkan beberapa media pembelajaran, aktifitas yang dilakukan setiap hari yaitu sebelum memulai pembelajaran dikelas anak didik dirapikan, kemudian mengucapkan salam dan berdoa sebelum belajar.

Pada kegiatan inti langkah masih sama seperti pertemuan sebelumnya namun dengan materi yang berbeda. Pada Kegitan inti guru melakukan apersepsi dengan menunjukkan gambar anggota tubuh dan anak bersama-sama menebak gambar yang ditunjuk guru tersebut. Kegiatan dilanjutkan, anak yang sudah menebak antusias menebak gambar yang ditunjukkan, namun pada gambar punggung, pinggang paha dan betis, hanya beberapa anak yang masih semangat berteriak, banyak anak yang diam ketika gambar yang dilihat membingungkan mereka. Guru kemudian membantu dengan menunjukkan gambar yang hampir sama tersebut dan menjelaskan perbedaannya. Guru memberikan semangat bahwa semua pintar dan mampu menebak fungsi gambar yang ditebak kemudian menjelaskan cirri dan fungsi gambar yang ditebak. Selanjutnya guru dan peneliti memberi penjelasan bahwa hari ini akan melaksanakan permainan tebak gambar, dan menjelaskan aturan permainannya. Aturan permainan pada lomba menebak yaitu anak yang harus dengan cepat menebak gambar yang dilihat, dan menyebutkan fungsi gambar yang dilihat, Ketika menebak anak menyebutkan fungsi dari gambar yang ditebaknya. Selanjutnya guru memperlihatkan salah satu gambar anggota tubuh untuk di tebak. Anak yang menebak duluan kemudian menyebutkan fungsi anggota anggota tubuh yang di tebaknya. Anak yang dapat menebak dan mengingat fungsi anggota tubuh berhak mendapat bintang empat. Saat pertemuan ketiga ini anak-anak masih terkondisi yaitu terlihat kurang dari antusiasme anak dalam mengikuti permainan.

Kegiatan akhir anak-anak dipersilakan istirahat dan membereskan alat main yang digunakan. Setelah itu guru memberikan kesimpulan tentang kegiatan yang dilakukan hari ini yaitu peningkatan kemampuan daya ingat melalui permainan tebak gambar, setelah itu menyanyikan beberapa lagu dan mengucapkan doa sebelum pulang.

Pelaksanaan tindakan Siklus II pertemuan IV dilaksanakan pada hari Kamis, 2 Agustus 2018 pada pukul 07.30 - 10.00 WITA di kelompok B PAUD Bintang 9 kelurahan Lalolara dengan menggunakan tema Diri sendiri dan sub tema anggota tubuh (Badan). Adapun indikator yang harus dicapai anak didik pada setiap pertemuan yaitu: anak dapat menyebutkan bagian anggota tubuh, anak dapat menebak dengan benar gambar bagian anggota tubuh, menebak dengan benar fungsi gambar anggota tubuh yang di lihat, anak dapat memasangkan lambang bilangan sesuai jumlah gambar anggota tubuh. Sebelum kegitan pembelajaran dimulai, guru telah menyiapkan beberapa media pembelajaran, aktifitas yang dilakukan setiap hari yaitu sebelum memulai pembelajaran dikelas anak didik dirapikan, kemudian mengucapkan salam dan berdoa sebelum belajar.

Pada kegiatan inti langkah masih sama seperti pertemuan sebelumnya namun dengan materi yang berbeda. Pada Kegitan inti guru melakukan apersepsi dengan menunjukkan gambar anggota tubuh dan anak bersama-sama menebak gambar yang ditunjuk guru tersebut. Kegiatan dilanjutkan, anak yang sudah menebak antusias menebak gambar yang ditunjukkan, namun pada gambar punggung, pinggang paha dan betis, hanya beberapa anak yang masih semangat berteriak, banyak anak yang diam ketika gambar yang dilihat membingungkan mereka. Guru kemudian membantu dengan menunjukkan gambar yang hampir sama tersebut dan menjelaskan perbedaannya. Guru memberikan semangat bahwa semua pintar dan mampu menebak fungsi gambar yang ditebak kemudian menjelaskan cirri dan fungsi gambar yang ditebak. Selanjutnya guru dan peneliti memberi penjelasan bahwa hari ini akan melaksanakan permainan tebak gambar, dan menjelaskan aturan permainannya. Aturan permainan pada lomba menebak yaitu anak yang 
harus dengan cepat menebak gambar yang dilihat, dan menyebutkan fungsi gambar yang dilihat, Ketika menebak anak menyebutkan fungsi dari gambar yang ditebaknya. Selanjutnya guru memperlihatkan salah satu gambar anggota tubuh untuk di tebak. Anak yang menebak duluan kemudian menyebutkan fungsi anggota anggota tubuh yang di tebaknya. Anak yang dapat menebak dan mengingat fungsi anggota tubuh berhak mendapat bintang empat. Saat pertemuan ketiga ini anak-anak masih terkondisi yaitu terlihat kurang dari antusiasme anak dalam mengikuti permainan.

Kegiatan akhir anak-anak dipersilakan istirahat dan membereskan alat main yang digunakan. Setelah itu guru memberikan kesimpulan tentang kegiatan yang dilakukan hari ini yaitu peningkatan kemampuan daya ingat melalui permainan tebak gambar, setelah itu menyanyikan beberapa lagu dan mengucapkan doa sebelum pulang.

Hasil analisis observasi guru sesuai dengan lembar observasi sebanyak 15 aspek yang harus dicapai oleh guru. Pada siklus II persentase aspek yang diamati mencapai $93,33 \%$ dengan rincian dari 15 aspek hanya 14 aspek yang dilaksanakan. Aspek yang diamati diantaranya yaitu: (1) guru mengucapkan salam, (2) guru membimbing anak untuk berdoa sebelum belajar, (3) guru mempersiapkan anak belajar, (4) guru menyiapkan media yang yang berhubungan dengan permainan tebak gambr, (5) guru memperkenlkan media pebelajaran berupa kartu gambar, (6) guru mejelaskan permainan yang akan di lakukan, (7) guru meminta anak untuk memperhatikan kegiatan yang akan di lakukan, (8) guru meminta anak menyebutkan bagin anggota tubuh, (9) guru meminta anak menebak dengan benar bagian anggota tubuh, (10) guru meminta anak untuk menyebutkan fungsi anggota tubuh yang di tebaknya, (11) guru memantau anak dengan berkeliling dalam kelas saat anak sedang melakukan pembelajaran (12) guru meminta anak untuk mengerjakan tugas dengan tertib (13) guru melakukan tanya jawab mengenai kegiatan yng telah di lakukan (14) guru membimbing anak untuk berdoa sebelum pulang.

Sedangkan yang tidak tercapai sebanyak 1 aspek $(6,66 \%)$ yaitu guru tidak melakukan tanya jawab mengenai kegiatan yang dilakukan hari ini. Untuk lebih jelasnya dapat dilihat pada histogram berikut:

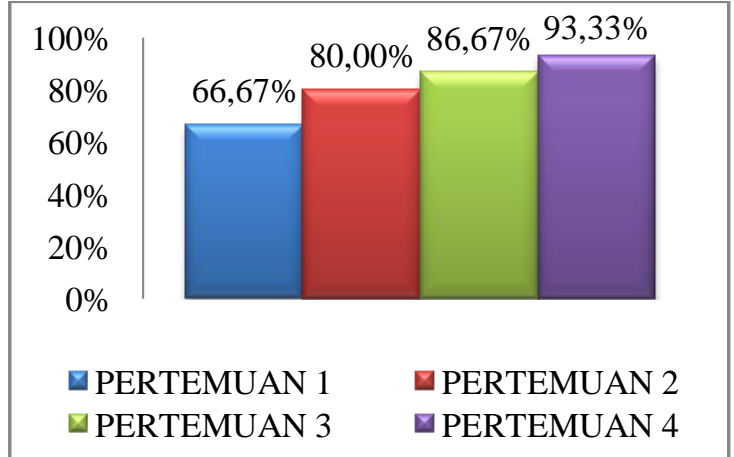

Gambar 3. Histogram Hasil Analisis Aktivitas Mengajar Guru Siklus II

Observasi terhadap anak didik meliputi mendengarkan guru menyampaikan tujuan pembelajaran, mendengarkan cerita guru dengan tertib, anak melakukan tanya jawab dengan guru tentang permainan tebak gambar, dan mendengarkan kesimpulan terhadap kegiatan yang dilakukan.

Hasil analisis aktivitas belajar anak sesuai dengan lembar observasi pada siklus II sebanyak 14 aspek yang diamati diharapkan dapat tercapai, namun yang tercapai sebanyak 13 aspek (92,85\%), aspek yang diamati diantaranya: (1) anak mempersiapkan diri untuk belajar, (2) anak mengucapkan salam, (3) Anak mendengarkan guru menyampaikan tujuan pembelajaran, (4) Anak mendengarkan guru meyampaikan tujuan pembelajaran, (5) anak mendengarkan guru menyampaikan materi pembelajaran tentang permainan tebak gambar, (6) anak dapat menyebutkan bagian anggota tubuh, (7) Anak mampu menebak dengan benar bagian anggot tubuh, (8) anak mampu menebak fungsi anggota tubuh yang telah di tebaknya, (9) Anak dapat memasangkan lambang bilangan sesuai jumlah gambar anggota tubuh, (10) Anak dapat menggambar dan mengwarnai gambar, (11) Anak dapat mengerjakan tugas dengan tertib, (12) Anak Melakukan tanya jawab dengan guru tentang kegiatan yang dilakukan, (13) anak bersama guru berdoa dan mengucapkan salam sebelum pulang.

Aspek yang tidak tercapai sebanyak 1 aspek dengan persentase 7,14\% yaitu (1) anak tidak melakukan tanya jawab dengan guru tentang kegiatan yang dilakukan.

Untuk lebih jelasnya dapat dilihat pada histogram berikut: 


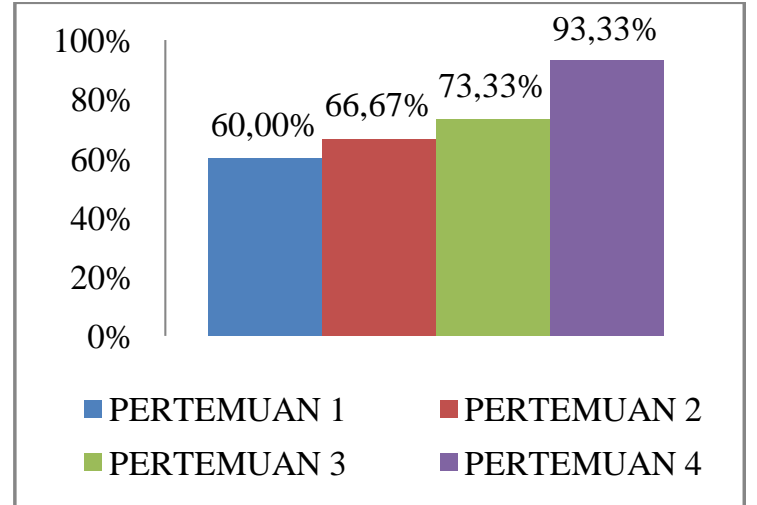

Gambar 4. Diagram Hasil Analisis Aktivitas Belajar Anak Didik Siklus II

Tabel 2. Nilai Klasikal pada Siklus II

\begin{tabular}{lcc}
\hline \multicolumn{1}{c}{ Kategori } & Jumlah & Persentase \\
$\begin{array}{l}\text { Berkembang } \\
\begin{array}{l}\text { Sangat Baik (BSB) } \\
\text { Berkembang Sesuai }\end{array}\end{array}$ & 8 & 58 \\
$\begin{array}{l}\text { Harapan (BSH) } \\
\text { Mulai Berkembang } \\
\text { (MB) }\end{array}$ & 5 & 31 \\
$\begin{array}{l}\text { Belum Berkembang } \\
\text { (BB) Jumlah }\end{array}$ & 0 & 11 \\
\hline
\end{tabular}

Berdasarkan data hasil perolehan nilai anak yang ditampilkan pada Tabel 4 tersebut, maka dapat disimpulkan bahwa secara klasikal perolehan nilai anak dalam kegiatan peningkatan kemampuan daya ingat pada kelompok B PAUD Bintang 9 Kelurahan Lalolara pada tahap evaluasi siklus II, rata-rata anak didik memperoleh nilai bintang (****) atau Berkembang Sangat Baik (BSB) yaitu sebanyak 8 orang anak dengan persentase $58 \%$, nilai bintang (***) atau Berkembang Sesuai Harapan (BSH) yaitu sebanyak 5 orang anak dengan persentase $31 \%$, untuk yang memperoleh nilai bintang $(* *)$ atau Mulai Berkembang (MB) yaitu sebanyak 3 orang anak dengan persentase $11 \%$ .Walaupun masih terdapat anak yang memperoleh nilai bintang (**) atau Mulai Berkembang (MB) tetapi dapat dikatakan bahwa sebagian besar anak dipandang telah mampu menyelesaikan tugas-tugas yang telah ditetapkan sesuai dengan indikator penilaian dalam penelitian ini khususnya dalam pelaksanaan tindakan siklus II. Selain itu dengan perolehan nilai sebesar 83,3\% tersebut telah dicapai oleh 16 orang anak, sehingga secara umum dapat dikatakan bahwa program kegiatan atau rangkaian pelaksanaan pembelajaran dalam peningkatan kemampuan daya ingat anak pada kelompok B PAUD Bintang 9 kelurahan Lalolara dipandang telah terselesaikan dan mencapai indikator kinerja yaitu $75 \%$.

\section{SIMPULAN DAN SARAN}

\section{Simpulan}

Berdasarkan hasil pengamatan aktivitas mengajar guru pada siklus 1 dari 15 aspek yang diamati pencapaian yang dilakukan terdapat 11 aspek $(73,33 \%)$ dan ketidaktercapaian terdapat 4 aspek (26,66\%). Sedangkan siklus II kegiatan aktivitas guru yang diamati dari 15 aspek tercapai 14 aspek $(93,33 \%)$ dan ketidak ketercapaian 1 aspek $(6,66 \%)$.

Sedangkam hasil pengamatan aktivitas mengajar anak pada siklus 1 dari 14 aspek yang diamati pencapaian yang dilakukan terdapat 10 aspek $(71,42 \%)$ dan ketida ketercapaian terdapat 4 aspek $(28,57 \%)$. Sedangkan siklus II kegiatan aktivitas anak yang diamati dari 14 aspek tercapai 13 aspek $(92,85 \%)$ dan ketidak ketercapaian 1 aspek $(7,14 \%)$.

Dengan demikian dapat disimpulkan bahwa daya ingat anak di kelompok B PAUD Bintang Sembilan Kelurahan LalolarA dapat ditingkatkan melalui kegiatan permainan kartu tebak gambar.

\section{Saran}

Setelah melaksanakan tindakan penelitian maka peneliti menyarankan hal-hal diantaranya dalam pelaksanaan pembelajaran maka hendaknya mempertimbangkan materi, media, dan strategi yang tepat untuk anak didik dan guru dituntut untuk selalu kreatif dan inovatif dalam melaksanakan kegiatan-kegiatan yang dapat meningkatkan potensi anak didik.

\section{DAFTAR PUSTAKA}

Depdiknas. 2003. Undang-undang Nomor 20 Tahun 2003. Tentang Sistem Pedoman Penilaian Pendidikan.

\section{Pedoman Penilaian di Taman} Kanak-Kanak. Jakarta: Depdiknas.

Heris \& Afrilianto. 2017. Langkah Praktis Tindakan Penelitian Kelas bagi Guru. Bandung: Rineka Cipta.

Slamet, Suyanto. 2005. Pembelajaran untuk Anak TK. Jakarta: Pustaka.

Winataputra, dkk. 2005. Strategi Belajar Mengajar. Jakarta: Universitas Terbuka. 